Article

\title{
Directional Distance Function Technical Efficiency of Chili Production in Thailand
}

\author{
Wirat Krasachat ${ }^{1, *(\mathbb{D})}$ and Suthathip Yaisawarng ${ }^{2}$ (D) \\ 1 KMITL Business School, King Mongkut's Institute of Technology Ladkrabang, Bangkok 10520, Thailand \\ 2 Economics Department, Union College, Schenectady, NY 12308, USA; yaisawas@union.edu \\ * Correspondence: wirat.kr@kmitl.ac.th
}

check for updates

Citation: Krasachat, W.; Yaisawarng, S. Directional Distance Function Technical Efficiency of Chili Production in Thailand. Sustainability 2021, 13, 741. https://doi.org/ $10.3390 /$ su13020741

Received: 25 November 2020 Accepted: 12 January 2021 Published: 14 January 2021

Publisher's Note: MDPI stays neutral with regard to jurisdictional clai$\mathrm{ms}$ in published maps and institutional affiliations.

Copyright: () 2021 by the authors. Licensee MDPI, Basel, Switzerland. This article is an open access article distributed under the terms and conditions of the Creative Commons Attribution (CC BY) license (https:// creativecommons.org/licenses/by/ $4.0 /)$.

\begin{abstract}
To overcome the challenging food safety and security problem, in 2003, the Thai government initiated 'Good Agricultural Practices' (GAP) technology. This paper used a sample of 107 small chili farms from the Chiyaphoom province for the 2012 crop year, and data envelopment analysis (DEA) meta-frontier directional distance function technique to answer two questions: (1) Are GAP-adopting farms, on average, more efficient than conventional farms? (2) Does access to GAP technology affect farmers' decisions to adopt GAP technology? We also developed an 'indirect' approach to reduce the potential sample selection bias for small samples. For the dry-season subsample, GAP farms were more technically efficient when compared with non-GAP farms. These dry-season non-GAP farms may not adopt the GAP method because they have limited access to GAP technology. For the rainy-season subsample, on average, GAP farms were more efficient than non-GAP farms at the $5 \%$ level. Access to the GAP technology is not a possible reason for non-GAP rainy season farms to not adopt the GAP technology. To enable sustainable development, government agencies and nongovernmental organizations (NGOs) must develop and implement appropriate educational and training workshops to promote and assist GAP technology adoption for chili farms in Thailand.
\end{abstract}

Keywords: chili farm; directional distance function; environmental innovation; meta-frontier; technology adoption; sample selection bias; sustainability

\section{Introduction}

As the world population is increasing, food safety and security have become prominent and pressing issues. Food production requires natural resources, such as land and water. These natural resources are scarce. It is of the utmost importance to conserve, if not improve, these precious resources. Scientists, research practitioners, academic scholars, and policymakers have turned their attention to environmental innovations and sustainable development as potential avenues to address food safety and security. Following Aldieri et al. [1], this paper defined environmental innovations as innovations that are environmentally friendly, produce positive externalities, and lead to sustainable development. These environmental innovations also produce knowledge spillovers that further generate more sustainable development. For an excellent review of economic effects on environmental innovations, see Aldieri et al. [2].

The 'Good Agricultural Practices' (GAP) program, initiated by the Ministry of Agriculture and Cooperatives of Thailand in 2003, is an example of environmental innovation. Agricultural producers who adopt the GAP technology substitute chemical fertilizers for organic fertilizers, resulting in less pollution, better soil quality and nutrients, and better health for farmers and neighbors. If more farmers adopt GAP technology, the requisite natural resources would be preserved and sustained. Promoting GAP technology may also help farmers improve their productive efficiency and yield a win-win situation for farmers, consumers, and the economy. Clean technology, such as the GAP production practice, generates knowledge spillovers and positive effects on environment and productivity [2]. However, the impact on firms' technical efficiency is inconclusive. 
This paper attempts to answer two questions: Are GAP-adopting farms, on average, more efficient than conventional farms? Does access to GAP technology affect farmers' decisions to adopt GAP technology? In this paper, we analyzed 107 small chili GAP farms and conventional (i.e., non-GAP) farms in Thailand for the 2012 crop year. These farms grow chili either in the dry or rainy seasons, depending on their geographic locations. To control for 'operating environments,' we analyzed dry-season chili farms and rainy-season chili farms separately. The empirical techniques included data envelopment analysis (DEA) meta-frontiers and directional distance function. We computed and compared the directional technical (or productive) efficiency of GAP farms and conventional non-GAP farms. As participating in the GAP program is voluntary, potential sample selection bias exists. In this paper, we developed an 'indirect' approach to address sample selection bias for small samples.

In Thailand, chili production is important because chili is one of Thailand's cultural products. It is an essential ingredient of Thai meals in fresh, fried, grilled, and processed forms. The processed forms include chili's use in manufactured foods, such as chili paste, chili sauce, and instant noodles for domestic consumption and export. Conventional technology heavily uses chemicals and chemical fertilizers, and this chili produce is contaminated with chemical residues. Both characteristics not only harm the environment and human health but also prevent chili farmers from exporting their crop. As such, empirical findings could guide government agencies and nongovernmental organizations (NGOs) in developing and implementing appropriate educational and training workshops to promote and assist in GAP technology adoption.

Farmers from both groups could improve their productive efficiency and the quality of their chili to meet manufacturing and export standards, and, thus, their income. Therefore, using the GAP technology makes chili production sustainable. The findings can also be useful for environmental advocates to help potential consumers develop proper awareness and perceptions regarding safe produce. High-quality GAP chili and better consumer awareness regarding food safety would reinforce Thailand 4.0, the policy for moving Thailand forward initiated by the Thai Government [3].

The paper unfolds as follows. Section 2 presents background information on efficiency studies as well as the GAP program. Section 3 describes our DEA measure of directional distance function technical efficiency, the technology gap between group-specific frontiers and the meta-frontier, as well as testable hypotheses. Section 4 introduces the sample, approaches to reduce potential sample selection bias, and presents the findings. Section 5 concludes the paper.

\section{Background Information}

Sustainable development in the agriculture sector has received considerable attention from environmental advocates, decisionmakers, policymakers, and researchers for decades. This is because the agriculture sector plays an important role in addressing the world's growing need for food security and, at the same time, the sector consumes a substantial part of limited natural resources, such as land and water (i.e., the core issue of sustainable development $[4,5])$. Agriculture production must use technology that leads to sustainable development by conserving natural resources, enriching the quality of natural resources, improving human capital (i.e., skills, knowledge, and health), and improving production capability and efficiency.

Studies focusing on individual farm efficiency span different products and locations. For example, technical efficiency was analyzed for rice farms in Thailand [6-8], Vietnam [9-11], and Myanmar [12,13]. Padilla-Fernandez and Nuthall [14] and Murali and Prathap [15] addressed technical efficiency for sugarcane farms in the Philippines and India, respectively, while Madau [16,17] considered technical efficiency for citrus farms in Italy. Some studies focused on sustainable production, such as the effects of chemical pesticide use on efficiency and productivity [18-20]. Others focused on additional efficiency types, such as scale $[9,16,19,21]$ or allocative efficiency [22-24]. Studies on the efficiency of the agriculture 
sector often use not only farm-level data but also macro-level data. For example, Shaik and Miljkovic [25] and Hart et al. [26] used state- and country-level data, respectively, over multiple years to explore whether trade affects technical efficiency.

Existing studies on efficiency and productivity in agriculture have used two main techniques, i.e., data envelopment analysis (DEA) and stochastic frontier analysis (SFA), with different variations. These studies measure the efficiency of individual observations (e.g., farms, states, and countries) relative to the best observations in the same sample. They assumed that these individual observations minimize their resource use to produce predetermined output levels (input-orientation) or maximize output quantities from the available resources (output-orientation). A small but growing number of studies measure firms' technical efficiency by assuming these firms expand outputs while reducing inputs (reference [27-29] for agricultural farms; reference [30-32] for others). Again, these studies measure the efficiency of observations relative to the best observations in the same sample.

Past studies on chili production cover a broad range of areas. For example, Anuwarul Hug and Arshad [33], Mohammed et al. [34], Asravor et al. [35], Hossain [36], Pakpahan and Nababan [37], and Ngo et al. [38] measured the technical efficiency of chili production. Mariyono and Sumarno [39] studied farmers' decisions to grow chili instead of alternate crops, such as rice. Athipanyakul and Pak-Uthai [40] and Sriwaranun and Paku-Thai [41] are among scholars who focused on adopting GAP technology for chili growing. Ooraikul et al. [42] considered the health effects of high pesticide residue on chili products and reported that Thai chili growers used excessive pesticides before and after harvesting.

Wanwimolruk et al. [43] investigated pesticide residuals in vegetables purchased from markets in Thailand, while van Asselt et al. [44] identified and ranked chemical hazards with the highest human health risk for spices and herbs, such as chili, in the European Union. Khaitov et al. [45] used the experimental design approach to evaluate the impact of organic manure on chili production under three variable climate conditions. The authors concluded that the proper amount of organic manure under elevated temperature affected the chili growth and nutrient intake. The use of organic manure helped to retain soil water and reduced the water needed for production. Improving agricultural irrigation efficiency and the use of clean production technology could improve water resources [5].

In response to the food safety and security challenges, the Thai Ministry of Agriculture and Cooperatives initiated the good agricultural practice (GAP) program in 2003. Tuninetti et al. [4] found that agricultural practices were more important than climatic conditions in reducing the water needed to produce crops. Hence, the GAP program is the right step toward creating sustainable development in the fruit and vegetable production system (including chili) in Thailand. The GAP program regulates water sources, plantation area, and the application of pesticides and fertilizers both before and after harvesting. Biological controls and organic manure replaced chemical pesticides and chemical fertilizer, respectively, to reduce the product contamination risk. However, too much emphasis on pesticide contamination instead of on-farm practices may create an adverse outcome, i.e., increase use of chemical pesticide. It is important that the GAP program balances the agricultural practice and the quality of produce [46].

GAP includes guidance in the handling, harvesting, collecting, moving, and storing of products to ensure proper hygiene, quality, and safety of the product $[47,48]$. The Thai government actively promotes the GAP technology as a new agricultural practice through several workshops and hands-on assistance in the field. These workshops and hands-on assistance improved farmers' knowledge and skills. It is one method to build the human capital necessary for sustainable development [49]. Adopting the GAP technology is voluntary and farmers are strongly encouraged to do so. By helping farmers develop their ability to share their knowledge to assist other farmers, it creates knowledge spillovers that have positive effects on sustainability. Thus, the government effort could potentially reduce the obstacles for successful implementation of the GAP program, such as increased production costs and constraints on labor or management time, weak public extension, etc. [49-52]. 
An increase in food safety and quality awareness may contribute to differential prices of products both locally and internationally. Food safety and quality are gateways to export markets. In theory, farmers who adopt GAP and obtain certificates can command higher prices for their products and generate higher income $[50,53,54]$. GAP production, if it brings about technical efficiency improvement, would then be consistent with the food and agriculture segment of Thailand 4.0, which calls for transforming traditional farmers into smart farmers. The game plan for Thailand 4.0 is that smart farmers would create a competitive advantage for Thai producers globally. Smart agriculture would result in premium quality products that enable farmers to command high prices [3].

To our knowledge, none of these existing studies on chili production uses a directional distance function to address the issue of technical efficiency of chili production as it relates to GAP technology adoption, especially with farms in Thailand. This paper is a novel application of the directional distance function technique, and it offers three new contributions. First, it provides empirical evidence on the efficiency of chili production in Thailand. The directional distance function enabled us to assess each farm's technical efficiency by expanding its output and simultaneously reducing its resources. Thus, this technique does not require the a priori assumption that farmers want to minimize inputs or to maximize output while keeping the output level (or input level) constant.

Second, this paper is the first paper to apply directional technical efficiency measures to analyze chili production in a meta frontier framework. A study of Huang et al. [55] is one such example; the paper calculated the meta-frontier directional technical efficiency for the banking industry for 17 countries. Unlike Huang et al. [55], our paper uses a DEAtype, instead of an SFA-type, meta-frontier. Third, we developed a method to address the potential sample selection bias for small samples when the propensity matching approach is not feasible. An issue of sample selection bias arises from the fact that adopting GAP technology is voluntary.

\section{Methodology}

Let $x=\left(x_{1}, \ldots, x_{N}\right) \in \Re_{+}^{N}$ be a vector of $N$ inputs and $y=\left(y_{1}, \ldots, y_{M}\right) \in \Re_{+}^{M}$ be a vector of $M$ outputs. The production technology set $T$ is defined as:

$$
T=\left\{(y, x): x \in \Re_{+}^{N} \text { can produce } y \in \Re_{+}^{M}\right\} .
$$

For a sample of $K$ farms, the piecewise linear production technology set $T$ is:

$$
\begin{gathered}
T=\left\{(y, x): \sum_{k=1}^{K} z_{k} y_{k m} \geq y_{m}, m=1, \ldots, M, \sum_{k=1}^{K} z_{k} x_{k n} \leq x_{n}, n=1, \ldots, N,\right. \\
\left.\sum_{k=1}^{K} z_{k}=1, z_{k} \geq 0, k=1, \ldots, K\right\} .
\end{gathered}
$$

where intensity variable, $z_{k}$, is the weight on the $k$ th farm in creating the piecewise linear technology. Following Färe and Primont [56], this paper assumed that the technology set $T$ satisfies the convexity, closeness, and strong disposability in the output and input requirements. For variable returns to scale technology, the values of all intensity variables $z$ must add up to one [57]. Hence, the technology in (2) exhibits increasing returns to scale, constant returns to scale, and decreasing returns to scale at different regions of the technology frontier.

The technical efficiency for each farm can be measured relative to the technology set in (2). Past studies on the efficiency of chili farms [33-38] assumed that farms in the sample reduced their inputs for producing their predetermined levels of outputs or expanded outputs from available inputs. In other words, these studies focused on either input-oriented technical efficiency or output-oriented technical efficiency, relative to the technology set constructed from all farms in the sample. Recent and growing studies employ a directional distance function as a tool in measuring efficiency $[27,28,32,58-60]$. 
This recent method measures neither input- nor output-oriented technical efficiency since it enables individual farms to expand outputs and reduce inputs simultaneously.

This paper followed the studies mentioned above in that individual farms' technical efficiency was measured by allowing these farms to expand their outputs while reducing inputs. An interview of Mr. Weera Pak-Uthai, a Thai chili specialist (3 November 2017) revealed that farms that grow chili in the dry season are located near water sources, such as rivers or irrigation systems. They grow a type of chili that is good for sale as fresh chili or as supply to chili sauce manufacturing firms. Farms that grow chili in the rainy season are located in hilly areas with no access to water resources from rivers or irrigation systems. These farmers rely on rainfall so they grow a type of drought resistant chili that is very hardy and can survive even if there is no rain for a month or so. These farmers may have their own small reservoir to keep rainwater for use in their farms. Farmers who grow chili in the rainy season normally sell their produce as fresh chili and dried chili.

By analyzing rainy-season chili farms and dry-season chili farms separately, we controlled our technology set for different crop years that affected the type of chili grown, source and level of water required, and resistance to drought, among other aspects. For each crop year, we divided our sample into GAP farms and conventional farms and measured the directional technical efficiency of individual farms in each group relative to their own group frontier as well as the meta-frontier. Hayami and Ruttan [61] define a meta-production as an envelope of all production functions. The upper boundary of the meta-production function, an unrestricted technology, is a meta-frontier and is used as a benchmark for measuring the technical efficiency of heterogeneous production units in the sample (see, [62-64] for details).

Let $T^{G A P}, T^{N G A P}$, and $T^{m}$ be a GAP farm group-frontier technology, a non-GAP farm group-frontier technology, and a meta-frontier technology, respectively. First, consider the rainy-season farm group. All rainy-season GAP farms were used to construct the group-technology set for rainy-season GAP farms $\left(T^{G A P}\right)$ as specified in (2) where $T$ is replaced by $T^{G A P}$ and we measured each rainy-season GAP farm's technical efficiency relative to the GAP technology, using a directional distance function. More formally, let $g=\left(g_{x}, g_{y}\right)$ where $g_{x} \in \Re_{+}^{N}$ and $g_{y} \in \Re_{+}^{M}$ is the direction vector for which we will contract input $x$ and expand output $y$. The directional technology distance function $\vec{D}_{T^{G A P}}(\cdot)$ is defined as:

$$
\vec{D}_{T^{G A P}}\left(y, x ; g_{y}, g_{x}\right)=\sup _{\beta}\left\{\beta:\left(y+\beta g_{y}, x-\beta g_{x}\right) \in T^{G A P}\right\}, y \in \Re_{+}^{M}, x \in \Re_{+}^{N} .
$$

$\vec{D}_{T^{G A P}}(\cdot)$ has standard properties, as discussed in Chambers et al. [65].

Suppose that there are $K$ rainy season GAP farms, and each produces output $y=$ $\left(y_{1}, \ldots, y_{M}\right) \in \Re_{+}^{M}$ using input $x=\left(x_{1}, \ldots, x_{N}\right) \in \Re_{+}^{N}$ as previously defined. The technical efficiency score for farm $r, \vec{D}_{T G A P}^{r}(\cdot)$, is computed as the solution to the following linear programming (LP) problem:

$$
\vec{D}_{T G A P}^{r}\left(y_{r}, x_{r} ; g_{y_{r}}, g_{x_{r}}\right)=\max _{\beta, z} \beta
$$

subject to

$$
\begin{gathered}
\sum_{k=1}^{K} z_{k} y_{k m} \geq y_{r m}+\beta g_{y_{r m}}, m=1, \ldots, M \\
\sum_{k=1}^{K} z_{k} x_{k n} \leq x_{r n}-\beta g_{x_{r n}}, n=1, \ldots, N \\
\sum_{k=1}^{K} z_{k}=1
\end{gathered}
$$




$$
z_{k} \geq 0, k=1, \ldots, K \text {. }
$$

Information on the left-hand side of (4) belongs to all rainy season GAP farms, while information on the farm whose technical efficiency is being measured, i.e., Farm $r$, is reflected on the right-hand-side of (4).

Suppose $\left(y_{r}, x_{r}\right)$ is on the efficient boundary of the technology set $T^{G A P}$ (i.e., it is not possible to produce more output $y$ and use less input $x$ simultaneously while stays in the technology set $T^{G A P}$ ). Farm $r^{\prime}$ s value of the directional technology distance function, $\vec{D}_{T^{G A P}}^{r}(\cdot)$, is zero. If, however, it is possible to produce more output $y$ while using less of the input $x$, then $\vec{D}_{T}^{r}$ GAP $(\cdot)$ is greater than zero. Therefore, $\vec{D}_{T}^{r}$ GAP $(\cdot) \geq 0$ is a measure of the $\left(g_{x}, g_{y}\right)$ directional technical inefficiency. This reflects the deviation from the production boundary or frontier. Farms that are efficient within the group, i.e., $\vec{D}_{T}^{r}$ GAP $(\cdot)=0$ are efficient peers for inefficient farms in the group. This is a rainy-season GAP farm groupfrontier efficiency score.

To compute a rainy-season conventional (non-GAP) farm group-frontier efficiency score for farm $r$, i.e., $\vec{D}_{T^{N G A P}}^{r}(\cdot)$, we repeated the procedure above. Specifically, we replaced the $K$ rainy-season GAP farms in the LP formulation in (4) with all rainy-season conventional non-GAP farms. The solution to the LP problem in (4) when the conventional non-GAP farms were used was the directional technical efficiency scores for conventional farms relative to the conventional farm group frontier. In this case, the solution to (4) is a group-specific measure of directional technical efficiency for farm $r$ where the specific group is the rainy-season conventional non-GAP farms. Our empirical analysis repeated this procedure two more times: one for the dry-season GAP farms and the other for the dry-season conventional farms.

If technology is a reason why conventional farmers choose not to adopt GAP technology, we would expect that GAP farms form the meta-frontier. As a result, on average, conventional farms have limited access to the meta-frontier (i.e., the best available technology). We applied the meta-frontier concept, first introduced by O'Donnell et al. [64], in the context of the distance function and later extended to the context of the directional distance function by Huang et al. [55]. Unlike Huang et al. [55], this paper measured the directional technical efficiency for both the rainy-season GAP and rainy-season conventional farms relative to a DEA meta-frontier instead of an SFA meta-frontier. In our study, we constructed a meta-frontier technology $\left(T^{m}\right)$ twice; one for rainy-season farms and the other for dry-season farms.

The meta-frontier technology for rainy-season farms, for example, is constructed from all rainy-season GAP farms as well as rainy-season non-GAP farms. This is the technology in (2) where the generic notation $T$ is replaced by $T^{m}$. The number of farms in the sample $K$ is the sum of rainy-season GAP farms and rainy-season conventional, non-GAP farms. Then, the directional technical efficiency score for farm $r$ relative to the rainy-season farm meta-frontier $\left(\vec{D}_{T^{m}}^{r}(\cdot)\right)$ is computed by the LP formulation specified in (4) when a combined sample consisting of both rainy-season GAP and rainy-season conventional farms is used to form the frontier on the left-hand side of the LP model. Again, we repeated the process for a sample of dry-season GAP and dry-season conventional non-GAP farms.

This study tested whether conventional farms have limited access to the best available technology, thus, preventing them from adopting GAP technology. We first followed Huang et al. [55] in defining the technology gap measure (TGM) in the context of the directional distance function. As the meta-frontier envelops all group frontiers, it follows that, for any farm $r$ in the sample, the directional distance function relative to the group frontier is equal or smaller than the directional distance function relative to the meta-frontier [64]. This fact, combined with the translation property of the directional distance function, implies that, if farm $r$ is one of the GAP farms, TGM $=\vec{D}_{T^{m}}^{r}(\cdot)-\vec{D}_{T^{G A P}}^{r}(\cdot) \geq 0$ [55]. The larger TGM indicates that farm $r$ has more limited access to the meta-production technology. In other words, farm $r$ is more likely to adopt the less advanced technology. 
If farm $r$ is one of the conventional farms, TGM $=\vec{D}_{T^{m}}^{r}(\cdot)-\vec{D}_{T^{N G A P}}^{r}(\cdot) \geq 0$. A similar interpretation applies. Relative to the meta-frontier, when conventional farm $r$ is measured against its GAP farm efficient peers, this suggests that farm $r$ chooses not to adopt the GAP technology because the GAP technology is not accessible to it. Suppose the respective efficient peers for conventional, non-GAP farm $r$ belong to the non-GAP technology group. In that case, it could imply that farm $r$ already adopted the best available technology, but this is purely inefficient. Note that Battese and Rao [62] and O'Donnell et al. [64] defined TGM in the context of distance functions as a ratio, instead of an additive form, between the meta-frontier technical efficiency and the group-frontier technical efficiency. Nevertheless, the authors stated that TGM could be used to test whether production units have limited access to the best available, unrestricted technology.

In applying the directional distance function methodology, we must use a specific direction vector, $g=\left(g_{x}, g_{y}\right)$, as introduced earlier. Wang et al. [66] provided a literature review on techniques for choosing direction vectors, including the advantages and disadvantages of each technique. This is beyond the scope of this study. We summarized three types of direction vectors commonly used in existing studies: (i) $\left(g_{x}, g_{y}\right)=(x, y)$, (ii) $\left(g_{x}, g_{y}\right)=(\bar{x}, \bar{y})$, and (iii) $\left(g_{x}, g_{y}\right)=(1,1)$. The first type of direction vector uses an individual farm's input and output mix. That is, for each farm, we contract all inputs in the same proportion as its original inputs to preserve the mix of inputs used (or the current technology) and expand all outputs in the same proportion of its original outputs, keeping the original mix of outputs. For this direction vector, each farm will move in its own unique direction, and the efficiency measure will be in the same spirit as the Farrell radial efficiency measure. For example, if the direction vector $\left(g_{x}, g_{y}\right)=(x, 0)$, i.e., we contract all inputs, holding the outputs constant, we obtain the Farrell radial input-oriented efficiency. If the direction vector is $\left(g_{x}, g_{y}\right)=(0, y)$, i.e., we expand all outputs, holding the inputs constant, we obtain the Farrell radial output-oriented efficiency. See Färe and Grosskopf [67] and Färe, Grosskopf, and Margaritis [68] for further discussion where the Farell-efficiency measure is framed in terms of the distance functions.

The second type of direction vector uses the sample mean input and output mix. This indicates that all farms in the sample must contract all inputs and expand all outputs in the same direction, i.e., the mix of inputs and outputs at the sample mean. This direction vector implicitly assumes that all farms in the sample can adjust their input and output mixes, resulting in the change of their current technology. The third type of direction vector requires all farms to adjust their inputs and outputs in the same common direction of $(1,1)$. This direction facilitates efficiency aggregation.

For our empirical analysis presented in Section 4, we chose the first type of direction vector, i.e., $\left(g_{x}, g_{y}\right)=(x, y)$ for two reasons. First, we wanted our directional technical efficiency measure to be in the same spirit as the Farell efficiency measure. Second, we believed that it may not be feasible for some farms in our sample to change their technology.

\section{Analysis of Chili Farms in Thailand}

\subsection{The Sample, Selection Bias, and Outliers}

Although the Good Agricultural Practices (GAP) program was initiated in 2003, the Thai government agencies began to actively promote the GAP program for chili production in 2007. The pilot project covered two districts in Chaiyaphoom province in the Northeast of Thailand. Using a participatory action research approach, a research team was in the area offering several workshops on the GAP technology. These workshops help farmers acquire knowledge and skills, such as how to make organic fertilizers, how and when to apply the 'home-made' organic fertilizers, how to handle disease, etc.

Many farmers participated in the program while many other farmers did not or chose not to adopt the GAP technology. By 2011, there were 106 GAP farms and approximately 101 non-GAP farms in two districts in Chaiyaphoom province covered by the pilot project. Under the Thailand Research Grant TRG5380007 [69], a research team randomly selected farmers in the agricultural extension area covered by the pilot project and interviewed 
them using a structured questionnaire to collect information on the 2012 crop year. There were 107 completed surveys, representing 52\% of the total farm population. These 107 farms comprised 42 GAP farms (40\% of GAP farm population) and 65 non-GAP farms (64\% of non-GAP farm population). The sample was representative of the farm population under the pilot project.

This study utilized the sample obtained by a research team under the Thailand Research Grant [69]. The initial sample consisted of 107 owner-operated small chili farms in two districts of Chaiyaphoom province, Thailand, during the 2012 crop year. The sample includes 42 GAP farms (i.e., farms that adopted GAP) and another 65 conventional farms (i.e., farms that did not adopt GAP). Individual farms in either group produce one output, namely, chili measured in kilograms (kgs). They all use four inputs: cultivated land (rai), labor (man-days), chemical fertilizers (kilograms), and other inputs (constant 2010 Thai baht (THB)). These other inputs include seeds, pesticides, herbicides, water irrigation, and other small tools. We used the Thailand Producer Price Index, available from Census and Economic Information Center (CEIC) [70], to adjust the current value of all other inputs to constant THB to obtain physical units of the other inputs. This is analogous to the concept of real GDP as a physical unit of the aggregated goods and services a country produced (nominal GDP). In total, sixty farms grew chili in the rainy season, while 47 farms did so in the dry season. On average, the farmers had 33.4 years of cultivation experience. In total, $44 \%$ of farmers were male, and $23 \%$ had more than 6 years of schooling. Table 1 presents the descriptive statistics of the initial sample.

Table 1. Descriptive statistics of the initial sample $(n=107)$.

\begin{tabular}{|c|c|c|c|c|c|}
\hline Variables & Average & $\begin{array}{c}\text { Standard } \\
\text { Deviation (S.D.) }\end{array}$ & Min & Max & $\begin{array}{c}\text { Coefficient of } \\
\text { Variation (C.V.) }\end{array}$ \\
\hline Output (Kgs) & 1567.23 & 1224.63 & 120.7 & 6666.7 & 78.1 \\
\hline Land (Rai) & 1.87 & 1.49 & 0.3 & 10.0 & 79.7 \\
\hline Labor (Man days) & 64.73 & 41.94 & 19.8 & 267.5 & 64.8 \\
\hline Fertilizer (Kgs) & 77.19 & 51.48 & 0.003 & 295.0 & 66.7 \\
\hline Other Input (constant 2010 THB) & $15,106.55$ & 8010.81 & 4240.3 & $54,575.7$ & 53.0 \\
\hline Variety (rainy-season variety $=1$, dry-season variety $=0$ ) & 0.56 & 0.50 & 0.0 & 1.0 & 89.3 \\
\hline $\begin{array}{c}\text { Good agricultural practice (GAP) (GAP technology }=1 \text {, } \\
\text { non-GAP technology }=0)\end{array}$ & 0.39 & 0.49 & 0.0 & 1.0 & 125.6 \\
\hline Experience (Years) & 33.42 & 13.63 & 0.0 & 60.0 & 40.8 \\
\hline Gender $($ male $=1$, female $=0)$ & 0.44 & 0.50 & 0.0 & 1.0 & 113.6 \\
\hline $\begin{array}{c}\text { Education (more than } 6 \text { years of schooling }=1 ; \\
\text { otherwise }=0 \text { ) }\end{array}$ & 0.23 & 0.43 & 0.0 & 1.0 & 186.9 \\
\hline
\end{tabular}

The initial data set may be relatively small; however, it processes several desirable characteristics. First, the quality of the survey data is good; the information was collected by a research team familiar with the location and production. The research team's expertise made it easier to notice unusual or inaccurate data and make corrections. Second, the GAP workshops were opened to all farmers in the area covering by the pilot project free of charge. Individual farmers decided whether to attend some or all workshops. After attending these workshops, certain farmers decided to adopt the GAP technology and continued working with the research team. Others decided not to adopt the GAP technology. Individual farmers also had the option to ignore the GAP workshops that they accessed.

Thus, this data set enables us to compare the efficiency between farms that adopted the GAP technology and those that did not, without confounding the effect of inefficient use of resources and not knowing how to use the resources under the GAP technology properly. Third, the sample is homogenous in terms of the geographic location (i.e., all farms are in the same province), climate (e.g., rainfall, temperature, humidity, and wind), and soil quality. Climate and soil quality affect the yield of chili production. Since this data set is homogenous, there is no need to find proxy variables to correct the heterogeneity of the sample to make the DEA efficiency analysis more accurate. 
As adopting GAP practice is voluntary, we may experience a sample selection bias. One way to remove an observable sample selection bias is to use the matching procedure technique. This statistical technique requires a relatively large sample to estimate the propensity score model (PSM) based on characteristics of farms that are exogenous from farmers' decisions to adopt GAP practice. The ultimate goal was to create a sample of GAP farms and conventional farms with similar exogenous characteristics. This study did not consider the geographic location of farms as a potential determinant for the observable sample selection bias because all farms in our initial sample were located in the same geographic region, experiencing similar types of weather, climate, and soil quality. Instead, we considered two possible exogenous characteristics, namely, farm size and the cultivation experience of farmers. Farm size was measured by the cultivated land for chili production. The cultivation experience of farmers was measured in years.

Due to a limited number of farms in our sample, the PSM method was eschewed, and an 'indirect' procedure was developed to reduce the potential observable sample selection bias as follows. First, the initial sample was classified into four groups. Group 1 consisted of conventional, non-GAP farms that grow chili in the dry season. Group 2 comprised conventional, non-GAP farms that grow chili in the rainy season. Group 3 included GAP farms that grow chili in the dry season. Group 4 consisted of GAP farms that grow chili in the rainy season. Second, descriptive statistics of farm size (i.e., land) and experience were calculated separately for each group. Third, the group mean was tested for whether the GAP farms' average size was the same as the average size of conventional, non-GAP farms using ANOVA and non-parametric Wilcoxon two-sample tests. More specifically, we compared the average farm sizes (or average experience) between Group 1 and Group 3, Group 2 and Group 4, as well as Group 1 plus Group 2 vs. Group 3 plus Group 4. If the null hypothesis was rejected, potential outliers in each group were removed, and steps 2 and 3 were repeated until the null hypothesis failed to reject. This procedure reduced our sample to 42 GAP farms and 52 conventional, non-GAP farms.

Table 2 displays the descriptive statistics of exogenous farm characteristics in our final sample by group as well as the test statistics under the null hypothesis that no difference in the average farm size between Group 1 and Group 3 (Group 2 vs. Group 4; conventional non-GAP farms (Group 1 plus Group 2) vs. GAP farms (Group 3 plus Group 4)). The alternative hypothesis is that the average farm size differs between the two respective groups. Based on ANOVA and non-parametric Wilcoxon two-sample tests, we do not have evidence to reject the null hypothesis that there is no difference in the average farm size in all cases at the 5\% level of significance. Similarly, the differences in the farmers cultivated experience between relevant groups were tested, and the no difference in the farmers' average cultivated experience failed to reject at the $5 \%$ level for all cases. These results suggest that the sample might not be prone to the sample selection bias.

As DEA is sensitive to outliers, we began by checking whether our data set included outlying farms. We computed the output per each input and looked for extreme ratios. One conventional farm growing chili in the rainy season had extremely high output per worker, while two other conventional, non-GAP farms growing chili in the rainy season had abnormally high output per kilogram of fertilizers due to reporting an unusually low amount of fertilizers used. A total of two other potential outliers were rainy-season GAP farms; one with an extremely high output per rai of cultivated land, and the other with an extremely high output per kilogram of fertilizers. In total, we excluded three conventional, non-GAP farms and two GAP farms, resulting in 49 conventional non-GAP and 40 GAP farms. Table 3 presents the descriptive statistics of the output and input variables in the final sample, excluding the outliers, classified by technology type and crop year. 
Table 2. Descriptive statistics of exogenous farm characteristics by group.

\begin{tabular}{|c|c|c|c|c|}
\hline Variable & Average & S.D. & Minimum & Maximum \\
\hline \multicolumn{5}{|c|}{ Group 1: Dry-Season, non-GAP farms $(n=17)$} \\
\hline Farm size (rai) & 1.90 & 0.90 & 0.25 & 3.0 \\
\hline Cultivation Experience (years) & 38.94 & 12.99 & 18.0 & 60.0 \\
\hline \multicolumn{5}{|c|}{ Group 2: Rainy-Season, non-GAP farms $(n=35)$} \\
\hline Farm size (rai) & 1.31 & 0.61 & 0.25 & 3.0 \\
\hline Cultivation Experience (years) & 34.40 & 9.98 & 20.00 & 60.0 \\
\hline \multicolumn{5}{|c|}{ Group 3: Dry-Season, GAP farms $(n=21)$} \\
\hline Farm size (rai) & 1.56 & 0.68 & 0.50 & 3.0 \\
\hline Cultivation Experience (years) & 37.14 & 12.00 & 20.00 & 60.0 \\
\hline \multicolumn{5}{|c|}{ Group 4: Rainy-Season, GAP farms $(n=21)$} \\
\hline Farm size (rai) & 1.52 & 0.59 & 1.00 & 3.0 \\
\hline Cultivation Experience (years) & 35.10 & 10.27 & 18.00 & 55.0 \\
\hline Hypothesis & \multicolumn{2}{|c|}{ ANOVA Test } & \multicolumn{2}{|c|}{ Wilcoxon Two-Sample Test } \\
\hline $\mathrm{H}_{0}$ : No difference in average farm size between & \multicolumn{2}{|c|}{ F-value $=1.76$} & \multicolumn{2}{|c|}{ Z-value $=1.20$} \\
\hline Group 1 and Group 3 & \multicolumn{2}{|c|}{ Prob $>F=0.19$} & \multicolumn{2}{|c|}{$\operatorname{Pr}>|\mathrm{Z}|=0.23$} \\
\hline $\mathrm{H}_{0}$ : No difference in average farm size between & \multicolumn{2}{|c|}{ F-value $=1.55$} & \multicolumn{2}{|c|}{$Z$-value = 1.41} \\
\hline Group 2 and Group 4 & \multicolumn{2}{|c|}{ Prob $>F=0.22$} & \multicolumn{2}{|c|}{$\operatorname{Pr}>|Z|=0.16$} \\
\hline $\mathrm{H}_{0}$ : No difference in average farm size between & \multicolumn{2}{|c|}{ F-value $=0.06$} & \multicolumn{2}{|c|}{$\mathrm{Z}$-value $=0.58$} \\
\hline Non-GAP farms and GAP farms & \multicolumn{2}{|c|}{ Prob $>F=0.81$} & \multicolumn{2}{|c|}{$\operatorname{Pr}>|Z|=0.56$} \\
\hline $\mathrm{H}_{0}$ : No difference in average years of experience & \multicolumn{2}{|c|}{ F-value $=0.20$} & \multicolumn{2}{|c|}{ Z-value $=0.24$} \\
\hline between Group 1 and Group 3 & \multicolumn{2}{|c|}{ Prob $>F=0.66$} & \multicolumn{2}{|c|}{$\operatorname{Pr}>|Z|=0.81$} \\
\hline $\mathrm{H}_{0}$ : No difference in average years of experience & \multicolumn{2}{|c|}{ F-value $=0.06$} & \multicolumn{2}{|c|}{$Z$-value $=0.19$} \\
\hline between Group 2 and Group 4 & \multicolumn{2}{|c|}{ Prob $>F=0.80$} & \multicolumn{2}{|c|}{$\operatorname{Pr}>|Z|=0.85$} \\
\hline $\mathrm{H}_{0}$ : No difference in average years of experience & \multicolumn{2}{|c|}{ F-value $=0.01$} & \multicolumn{2}{|c|}{ Z-value = 0.19} \\
\hline between non-GAP farms and GAP farms & \multicolumn{2}{|c|}{ Prob $>F=0.92$} & \multicolumn{2}{|c|}{$\operatorname{Pr}>|Z|=0.85$} \\
\hline
\end{tabular}

Note: ${ }^{\prime * * * \prime},{ }^{\prime * * \prime}$, and ${ }^{\prime * \prime}$ denote significance at the $1 \%, 5 \%$, and $10 \%$ levels, respectively.

Refer to Table 3. Comparing the dry-season GAP farms and rainy-season GAP farms, rainy-season GAP farms, on average, produced more chili per farm and used twice as much labor as the dry-season GAP farms. These differences might be in part due to the different types of chili grown in the rainy and dry seasons and other factors. GAP farms were about the same average size of 1.5 rai (or 0.24 hectares) for both seasons. All rainy-season GAP farms were very similar as indicated by the coefficients of variation. A similar pattern appeared for all dry-season GAP farms, except for the use of fertilizers, which appeared to vary widely across farms. In addition, dry-season GAP farms were operated by male farmers more than rainy-season GAP farms (0.62 vs. 0.26).

However, only $10 \%$ of dry-season GAP farmers had more than 6 years of education, compared to $26 \%$ for rainy-season GAP farmers. Between dry-season and rainy-season non-GAP farms, the rainy-season non-GAP farms, on average, produced more chili per farm than dry-season non-GAP farms. However, the average farm size for rainy-season non-GAP farms was 1.3 rai, slightly smaller than the average 1.9 rai for dry-season nonGAP farms. Rainy-season, non-GAP farms, on average, used marginally more fertilizers than dry-season, non-GAP farms. In terms of the farmers' gender and education, a similar pattern between GAP farms existed. Specifically, more male farmers operated dry-season, non-GAP farms compared with rainy-season, non-GAP farms ( 0.65 vs. 0.25$)$; however, these dry-season, non-GAP farmers were less educated than those who operated rainy-season, non-GAP farms ( 0.18 vs. 0.28$)$.

From Table 3, one can infer that GAP farms, on average, produced more chili output and used less fertilizers than non-GAP farms within the same crop year. Dry-season GAP farms used less labor than dry-season, non-GAP farms on average. The opposite was 
found for the labor usage of rainy-season farms. Different farm sizes (i.e., cultivated land) between GAP and non-GAP farms may contribute to this finding. To further explore this issue, this study investigated the chili output per unit of input (i.e., land, labor, fertilizers, and other inputs).

We compared the average output per unit of respective input between GAP and non-GAP farms for the same crop year type. The data showed that GAP farms produced more output per rai of land and obtained more yield per worker and per kilogram of fertilizers used. Within each variety (i.e., dry-season or rainy-season), GAP and non-GAP farms possessed similar characteristics in terms of experience farming, gender, and years of schooling. Owners of dry-season farms were more likely to be male, less educated, and had slightly more years of experience than owners of rainy-season farms.

Table 3. Descriptive statistics of GAP and non-GAP farms by season (outliers excluded).

\begin{tabular}{|c|c|c|c|c|c|}
\hline Variables & Average & S.D. & Min & Max & C.V. \\
\hline \multicolumn{6}{|c|}{ Group 1: Dry-Season, Non-GAP Farms, $n=17$} \\
\hline Output (Kgs) & 543.25 & 287.71 & 123.25 & 986.0 & 53.0 \\
\hline Land (Rai) & 1.90 & 0.90 & 0.25 & 3.0 & 47.4 \\
\hline Labor (Man days) & 61.47 & 29.63 & 22.00 & 136.0 & 48.2 \\
\hline Fertilizer (Kgs) & 65.96 & 39.91 & 15.00 & 190.0 & 60.5 \\
\hline Other Input (constant 2010 THB) & $13,694.82$ & 6535.66 & 4132.96 & $25,999.1$ & 47.7 \\
\hline Experience (years) & 38.94 & 12.99 & 18.00 & 60.0 & 33.4 \\
\hline Gender & 0.65 & 0.49 & 0.00 & 1.0 & 75.4 \\
\hline Education & 0.18 & 0.39 & 0.00 & 1.0 & 216.7 \\
\hline \multicolumn{6}{|c|}{ Group 2: Rainy-Season, Non-GAP Farms, $n=32$} \\
\hline Output (Kgs) & 1529.03 & 781.64 & 529.57 & 3543.0 & 51.1 \\
\hline Land (Rai) & 1.30 & 0.58 & 0.50 & 3.0 & 44.6 \\
\hline Labor (Man days) & 61.61 & 45.65 & 22.88 & 229.7 & 74.1 \\
\hline Fertilizer (Kgs) & 89.16 & 49.74 & 25.0 & 200.0 & 55.8 \\
\hline Other Input (constant 2010 THB) & $12,249.65$ & 5295.99 & 4411.22 & $25,834.4$ & 43.2 \\
\hline Experience (years) & 34.03 & 9.87 & 20.00 & 60.0 & 29.0 \\
\hline Gender & 0.25 & 0.44 & 0.00 & 1.0 & 176.0 \\
\hline Education & 0.28 & 0.46 & 0.00 & 1.0 & 164.3 \\
\hline \multicolumn{6}{|c|}{ Group 3: Dry-Season GAP Farms, $n=21$} \\
\hline Output (Kgs) & 713.97 & 285.50 & 270.00 & 1485.0 & 40.0 \\
\hline Land (Rai) & 1.56 & 0.68 & 0.50 & 3.0 & 43.6 \\
\hline Labor (Man days) & 43.83 & 13.14 & 19.75 & 67.9 & 30.0 \\
\hline Fertilizer (Kgs) & 62.47 & 66.10 & 6.00 & 295.0 & 105.8 \\
\hline Other Input (constant 2010 THB) & $14,019.36$ & 6866.43 & 3979.59 & $24,882.7$ & 49.0 \\
\hline Experience (years) & 37.14 & 12.00 & 20.00 & 60.0 & 32.3 \\
\hline Gender & 0.62 & 0.50 & 0.00 & 1.0 & 80.6 \\
\hline Education & 0.10 & 0.30 & 0.00 & 1.0 & 300.0 \\
\hline \multicolumn{6}{|c|}{ Group 4: Rainy-Season GAP Farms, $n=19$} \\
\hline Output (Kgs) & 2716.03 & 1099.87 & 1000.00 & 5296.5 & 40.5 \\
\hline Land (Rai) & 1.52 & 0.60 & 1.00 & 3.0 & 39.5 \\
\hline Labor (Man days) & 86.52 & 22.61 & 43.76 & 120.0 & 26.1 \\
\hline Fertilizer (Kgs) & 78.50 & 38.57 & 20.00 & 170.0 & 49.1 \\
\hline Other Input (constant 2010 THB) & $13,078.33$ & 4047.92 & 8341.16 & $18,072.0$ & 31.0 \\
\hline Experience (years) & 33.53 & 9.48 & 18.00 & 55.0 & 28.3 \\
\hline Gender & 0.26 & 0.45 & 0.00 & 1.0 & 173.1 \\
\hline Education & 0.26 & 0.45 & 0.00 & 1.0 & 173.1 \\
\hline
\end{tabular}




\subsection{Directional Distance Function Technical Efficiency and Technology Gap Measure \\ 4.2.1. Dry-Season Farms}

Table 4 panel (a) summarizes the directional distance function technical efficiency results relative to the group frontier and the meta-frontier as well as the respective technology gap measures for dry-season farms. Recall that a farm whose value of the directional distance function is zero is technically or productively efficient. It cannot expand its current output and simultaneously decrease its inputs relative to the respective technology frontier. On average, dry-season GAP farms were relatively directional technical efficient relative to their own frontier with an average score of 0.039 . There are seven farms that formed the dry-season group frontier. The farm that was the most directional technical inefficient in this group had an efficiency score of 0.184 .

Table 4. Directional distance function technical efficiency results.

\begin{tabular}{|c|c|c|c|c|c|}
\hline \multicolumn{6}{|l|}{ a. Dry-Season Farms } \\
\hline & Average & S.D. & Min & Max & $\begin{array}{l}\text { Efficient } \\
\text { Farms }\end{array}$ \\
\hline \multicolumn{6}{|c|}{ Relative to their own-group frontier } \\
\hline Dry-Season, GAP Farms DT $\left(\vec{D}_{T^{G A P}}\right)$ & 0.039 & 0.061 & 0 & 0.184 & 7 \\
\hline Dry-Season, Non-GAP Farms DT $\left(\vec{D}_{T^{N G A P}}\right)$ & 0.060 & 0.118 & 0 & 0.372 & 8 \\
\hline \multicolumn{6}{|c|}{ Relative to the meta frontier } \\
\hline Dry-Season, GAP Farms DT $\left(\vec{D}_{T^{m}}^{G A P}\right)$ & 0.039 & 0.062 & 0 & 0.184 & 7 \\
\hline Dry-Season, Non-GAP Farms DT $\left(\vec{D}_{T^{m}}^{N G A P}\right)$ & 0.156 & 0.166 & 0 & 0.556 & 2 \\
\hline Dry-Season, GAP Farms TGM & 0.0002 & 0.0009 & 0 & 0.004 & \\
\hline Dry-Season, Non-GAP Farms TGM & 0.096 & 0.084 & 0 & 0.218 & \\
\hline Hypothesis & \multicolumn{3}{|c|}{ ANOVA Test } & \multicolumn{2}{|c|}{ Wilcoxon Two-Sample Test } \\
\hline $\begin{array}{l}\mathrm{H}_{0} \text { : No difference in the average meta frontier Directional Technical } \\
\text { efficiency between dry-season GAP farms and dry-season Non-GAP } \\
\text { farms }\end{array}$ & \multicolumn{3}{|c|}{$\begin{array}{l}\text { F-value }=9.04^{* * *} \\
\text { Prob }>F=0.005\end{array}$} & \multicolumn{2}{|c|}{$\begin{array}{l}\text { Z-value }=2.57 * * \\
\operatorname{Pr}>|Z|=0.0101\end{array}$} \\
\hline $\begin{array}{l}\mathrm{H}_{0} \text { : No difference in the average Technology Gap Measure (TGM) } \\
\text { between dry-season GAP farms and dry-season Non-GAP farms }\end{array}$ & \multicolumn{3}{|c|}{$\begin{array}{l}\text { F-value }=27.59 * * * \\
\text { Prob }>F=<0.0001\end{array}$} & \multicolumn{2}{|c|}{$\begin{aligned} Z \text {-value } & =5.07 * * * \\
\operatorname{Pr}>|Z| & =<0.0001\end{aligned}$} \\
\hline \multicolumn{6}{|c|}{ b. Rainy-Season Farms } \\
\hline & Average & S.D. & Min & $\operatorname{Max}$ & $\begin{array}{l}\text { Efficient } \\
\text { Farms }\end{array}$ \\
\hline \multicolumn{6}{|c|}{ Relative to their own-group frontier } \\
\hline Rainy-Season GAP Farms DT $\left(\vec{D}_{T_{G A P}}\right)$ & 0.028 & 0.072 & 0 & 0.275 & 9 \\
\hline Rainy-Season, Non-GAP Farms DT $\left(\vec{D}_{T^{N G A P}}\right)$ & 0.070 & 0.098 & 0 & 0.356 & 6 \\
\hline \multicolumn{6}{|c|}{ Relative to the meta frontier } \\
\hline Rainy-Season GAP Farms DT $\left(\vec{D}_{T^{m}}^{G A P}\right)$ & 0.070 & 0.112 & 0 & 0.349 & 9 \\
\hline Rainy-Season, Non-GAP Farms DT $\left(\vec{D}_{T^{m}}^{N G A P}\right)$ & 0.116 & 0.122 & 0 & 0.406 & 3 \\
\hline Rainy-Season, GAP Farms TGM & 0.042 & 0.081 & 0 & 0.284 & \\
\hline Rainy-Season, Non-GAP Farms TGM & 0.045 & 0.048 & 0 & 0.159 & \\
\hline Hypothesis & \multicolumn{3}{|c|}{ ANOVA Test } & \multicolumn{2}{|c|}{ Wilcoxon Two-Sample Test } \\
\hline $\begin{array}{l}\mathrm{H}_{0} \text { : No difference in average meta frontier Directional Technical efficiency } \\
\text { between rainy-season GAP farms and rainy-season Non-GAP farms }\end{array}$ & \multicolumn{3}{|c|}{$\begin{array}{c}\text { F-value }=1.76 \\
\text { Prob }>F=0.1908\end{array}$} & \multicolumn{2}{|c|}{$\begin{array}{l}\text { Z-value }=-2.37^{* *} \\
\operatorname{Pr}>|Z|=0.0176\end{array}$} \\
\hline $\begin{array}{l}\mathrm{H}_{0} \text { : No difference in average Technology Gap Measure (TGM) between } \\
\text { rainy-season GAP farms and rainy-season Non-GAP farms }\end{array}$ & \multicolumn{3}{|c|}{$\begin{array}{c}\text { F-value }=0.02 \\
\text { Prob }>F=0.8777\end{array}$} & \multicolumn{2}{|c|}{$\begin{array}{l}Z \text {-value }=-1.96 * \\
\operatorname{Pr}>|Z|=0.0505\end{array}$} \\
\hline
\end{tabular}


Dry-season non-GAP farms, on average, were also relatively efficient compared to their own group frontier with an average score of 0.06 . A total of eight dry-season nonGAP farms formed the group frontier. Given the choice of their conventional, non-GAP technology, the directional technical efficiency of non-GAP farms varied by more than the GAP farm group as indicated by their respective standard deviation ( 0.118 for non-GAP farms vs. 0.061 for GAP farms). As it is not appropriate to compare the technical efficiency between dry-season GAP farms and dry-season non-GAP farms based on their group frontier results, we are now turning to the meta-frontier results.

Relative to the meta-frontier, dry-season GAP farms, on average, were more directional technical efficient than dry-season non-GAP farms (0.039 vs. 0.156). This conclusion was supported by the ANOVA test at the 1\% level of significance and by the Wilcoxon twosample test at the $5 \%$ level of significance. In total, nine farms formed the meta-frontier. Of these farms, seven were GAP farms, and the remaining two were non-GAP farms.

The fact that the meta-frontier is anchored almost exclusively by GAP farms and these GAP farms are the same as those formed the GAP-group frontier enables us to infer that the GAP technology dominated the conventional non-GAP technology and the meta frontier technology. As evident, the average technology gap measure (TGM) for dry-season GAP farms was 0.0002 , much less than the 0.096 average TGM for dry-season non-GAP farms at the $1 \%$ level of significance. For dry-season chili farms, conventional non-GAP farms have limited access to the meta frontier technology and the GAP technology.

Based on the meta-frontier results, we further scrutinized the efficient farms to find possible anecdotes that might help us gain insight into our quantitative analysis. Almost all inefficient farms, both GAP and conventional, non-GAP farms, had GAP farms as their efficient peers or role models. A couple of almost efficient GAP farms (with directional technical efficiency equal to zero if the efficiency score was rounded to four digits) also serve as peers for inefficient farms. These anecdotes support our finding discussed earlier.

Most serving efficient farms produced about $500 \mathrm{~kg}$ of chili per rai of cultivated land. However, it is not possible to narrow down the appropriate mix of inputs among labor, fertilizers, and other inputs. Some frequent efficient peers (i.e., efficient farms that serve as peers for inefficient farms multiple times) used more labor per rai of cultivated land than other frequent peers. This practice may reflect the art of farming that farmers must attend their farm frequently for early spotting of potential diseases, such as bacteria and viruses, applying bio-fertilizers, and correcting problems accordingly in a timely fashion, or both.

\subsubsection{Rainy-Season Farms}

Table 4 panel (b) summarizes the directional distance function technical efficiency results relative to the group frontier and the meta-frontier as well as their respective technology gap measures for rainy-season farms. Results from rainy-season farms paint a different picture compared to dry-season farms. Specifically, relative to their own rainyseason group frontiers, GAP farms' directional technical efficiency, on average, was 0.028 while that for non-GAP farms was 0.07. About half of the GAP farms were on their own group frontier, while slightly less than $20 \%$ of conventional, non-GAP farms were on the frontier. This finding suggests that, even if each farm operates within its homogenous technology choice to control possibly environmental differences, the conventional farm performance appeared to vary more than the GAP farm group.

The meta-frontier results that put both types of rainy-season farms against the common frontier revealed that the average directional technical efficiency of GAP farms of 0.07 was more efficient than the 0.116 average of conventional, non-GAP farms. Although this difference is statistically significant at the $5 \%$ level based on the Wilcoxon two-sample test, we failed to reject the null hypothesis based on the ANOVA test. Hence, our evidence is inconclusive. We reached a similar conclusion when comparing the average technology gap measure (TGM) between the two groups. Specifically, both groups had an average TGM of 0.04 , indicating that accessibility of the meta technology or the best available technology was not a reason for not adopting the GAP technology by rainy-season conventional farms. 
Based on the meta-frontier for rainy season farms, inefficient GAP and non-GAP farms had a mix of GAP and non-GAP efficient farms as their efficient peers. The most frequent peers were GAP farms. However, if we include efficient farms after rounding their efficiency score to four digits, there were two other efficient farms from the conventional farm group. The fact that frequent peers were from both groups supports our finding that both groups have equal access to the best available technology. In other words, neither technology, i.e., GAP vs. conventional, dominated; the prevailing meta technology is the mix of both GAP and conventional technologies. These frequent peers produced different chili levels, ranging from slightly above $1000 \mathrm{~kg}$ per rai to $2500 \mathrm{~kg}$ per rai. Similar to dry-season farms, no consistent pattern regarding to the use of various inputs emerged.

\section{Discussion and Conclusions}

Rainy-season chili farms in our sample had different experiences compared with dryseason chili farms. For rainy-season farms, both GAP and conventional, non-GAP farms are relatively efficient based on their own-group technology. The group technologies reflected different, perhaps unobserved environments, between GAP and non-GAP farms. The main differences between GAP and non-GAP farms were in the use of chemical pesticides and fertilizers (based on an interview of Mr. Weera Pak-Uthai, a Thai chili specialist). GAP farmers tended to use biological controls and organic manure instead of chemical pesticides and chemical fertilizers, respectively. They also follow the GAP guidelines that require waiting periods between applications of chemical pesticides and harvesting.

The proper waiting period helps minimize chemical residues. Therefore, chili grown under GAP is safer to consume. The meta-frontier results that put both GAP and conventional non-GAP farms on the same frontier enable us to compare the two groups' empirical results. Our empirical evidence is inconclusive. We cannot say with confidence that both groups differ in their directional technical efficiency and their ability to access the common best available technology (i.e., the meta frontier technology). For rainy-season farms, it appears that access to the GAP technology is not a reason for conventional, non-GAP farms not adopting GAP practice.

On the contrary, dry-season GAP farms and conventional, non-GAP farms were somewhat efficient relative to their own-group frontiers. Dry-season GAP farms appeared to have more similar directional technical efficiency than dry-season non-GAP farms. Some non-GAP farms had ample room for improvements. Relative to the meta-frontier, GAP farms, on average, were more technically efficient and had better access to the meta frontier technology compared with conventional, non-GAP farms at the $5 \%$ or better level of significance.

This finding agrees with Krasachat's [71] study, which reported that farmers who applied GAP were more technically efficient than those who did not use GAP in Thailand's chili farms. Unlike the rainy-season farms, dry-season conventional, non-GAP farms had limited access to the meta frontier technology mostly formed by GAP efficient peers. Hence, we infer that conventional farmers' decision to not adopt the GAP practices to produce environmentally safe chili depended on the ability to access the GAP technology.

Our results suggest that GAP technology access may prevent dry-season conventional farms from adopting the GAP technology. At the same time, this issue is irrelevant for rainy-season conventional farms. Government agencies, developing agencies, or both and NGOs should make the necessary efforts to educate dry-season conventional farmers about the GAP technology. Although both GAP and non-GAP farms were relatively efficient, on average, some farms were less efficient and had more room for improvement. Government agencies and NGOs could target these farms to help them improve their productive efficiency. More specifically, government agencies and NGOs could design and implement appropriate GAP training programs and promote the benefits of adopting GAP technology.

These benefits include improving farmers' health and self-esteem, potentially reducing the cost of fertilizers and pesticides, enhancing income from high product prices, and the 
privilege to access the safe agricultural products market. To make the implementation of training programs and promotions more effective, government agencies and NGOs may focus on young, well-educated farmers, a large family size, a small farm size, more experience in chili cultivation, expectations on cost reduction, and expectations on a higher price from the adoption. These factors positively affect farmers' GAP adoption $[40,41,72,73]$.

By building a strong community of GAP farmers, GAP farmers can help and support each other in solving their farm problems, such as soil degradation. The group may share knowledge and practices to enhance their technical efficiency further. The government might be more aggressive in promoting the adoption of the GAP technology. They may also tighten the aspects of the GAP program on the use of chemical fertilizers and food contamination, for example, to a stringent sustainable development policy.

As suggested in Aldieri et al. [1], a more stringent environmental policy could stimulate more environmental innovations, but it may also adversely affect firms' efficiency and productivity. Accompanying the stringency of the environmental aspects of the GAP practices, the government may attempt to lessen the negative effects along the line suggested by Siebrecht [49]. Past studies (see, for example, [53,54,72]) all found that GAP products received higher prices compared with the products produced by conventional farms. Subsequently, these chili GAP farms may raise their chili's quality to meet manufacturing and export standards and incomes. The ability to export chili products would reinforce the Thailand 4.0 goal.

It is also important to raise awareness regarding food safety among value chain actors, such as consumers, since government agencies and NGO support alone may not be sufficient (see, [52,72]). Promoting a better understanding of what the GAP certified products are to farmers and consumers could increase the demand for GAP certified products, enabling GAP farmers to command a higher price for their chili. However, some farmers may be unable to adopt GAP technology. These farmers may experience household labor constraints, a lack of land ownership, and a high farmer age. In addition, the initial high expectations regarding the market opportunities of the GAP-produced agricultural products and others might be unattainable $[40,72,73]$.

Author Contributions: Conceptualization, W.K. and S.Y.; methodology, S.Y.; software, S.Y.; validation, W.K. and S.Y.; formal analysis, S.Y.; investigation, W.K. and S.Y.; resources, W.K. and S.Y.; data curation, W.K. and S.Y.; writing-original draft preparation, S.Y.; writing—review and editing, W.K. and S.Y.; project administration, W.K.; funding acquisition, W.K. All authors have read and agreed to the published version of the manuscript.

Funding: This research was funded by the KMITL Business School (former Faculty of Administration and management), King Mongkut's Institute of Technology Ladkrabang, grant number 2561-0111019.

Institutional Review Board Statement: Not applicable.

Informed Consent Statement: Not applicable.

Data Availability Statement: Restrictions apply to the availability of these data. Data was obtained from the Thailand Research Grant TRG5380007 and are available from the corresponding author with the permission of the Thailand Research Fund.

Acknowledgments: This research was commenced when Suthathip Yaisawarng spent her sabbatical leave at King Mongkut's Institute of Technology Ladkrabang, Thailand. She appreciates the hospitality at the KMITL Business School and the release time from Union College, USA. Both authors acknowledge the funding support. Without this support, it would not have been possible to complete this project.

Conflicts of Interest: The authors declare no conflict of interest. 


\section{References}

1. Aldieri, L.; Makkonen, T.; Vinci, C.P. Environmental knowledge spillovers and productivity: A patent analysis for large international firms in the energy, water, and land resources fields. Resour. Policy 2020, 69, 101877. [CrossRef]

2. Aldieri, L.; Carlucci, F.; Vinci, C.P.; Yigitcanlar, T. Environmental innovation, knowledge spillovers and policy implications: A systematic review of the economic effects literature. J. Clean. Prod. 2019, 239, 118051. [CrossRef]

3. Acknowledge Management Institution. Thailand 4.0: Thriving in the 21st Century through Security, Prosperity \& Sustainability; Thailand Research Fund: Bangkok, Thailand, 2017.

4. Tuninetti, M.; Tamea, S.; D'Odorico, P.; Laio, F.; Ridolfi, L. Global sensitivity of high-resolution estimates of crop water footprint. Water Resour. Res. 2015, 51, 8257-8272. [CrossRef]

5. Wang, H.; Huang, J.; Zhou, H.; Deng, C.; Fang, C. Analysis of sustainable utilization of water resources based on the improved water resources ecological footprint model: A case study of Hubei Province, China. J. Environ. Manag. 2020, 262, 110331. [CrossRef]

6. Taraka, K.; Latif, I.A.; Shamsudin, M.N.; Sidique, S.B.A. Estimation of technical efficiency for rice farms in central Thailand using stochastic frontier approach. Asian J. Agric. Dev. 2012, 9, 1-11. [CrossRef]

7. Nunti, C.; Boonyakunakorn, P.; Sriboonchitta, S. Technical efficiency of rice production in Thailand: Copula-based stochastic frontier model. J. Phys. Conf. Ser. 2019, 1324, 012107. [CrossRef]

8. Jirarud, S.; Suwanmareepong, S. Technical efficiency of rice farmers under the large agricultural plot scheme in Khlong Khuean District, Chachoengsao Province, Thailand. World Rev. Entrep. Manag. Sustain. Dev. 2020, 16, 228-240. [CrossRef]

9. Linh, V.H. Efficiency of rice farming households in Vietnam. Int. Dev. Issues 2012, 11, 60-73, . [CrossRef]

10. Linh, L.T.; Lee, P.P.; Peng, K.C.; Chung, R.H. Factors influencing technical efficiency of rice farms in Dong Thap Province, Vietnam: An application of two-stage DEA. Am. Eurasian J. Agric. Environ. Sci. 2017, 7, 245-249. Available online: https: //www.idosi.org/aejaes/jaes17(3)17/9.pdf (accessed on 12 January 2021).

11. Nguyen, H.-D.; Ngo, T.; Le, T.D.; Ho, H.; Nguyen, H.T. The role of knowledge in sustainable agriculture: Evidence from rice farms' technical efficiency in Hanoi, Vietnam. Sustainability 2019, 11, 2472. [CrossRef]

12. Tun, Y.Y.; Kang, H.-J. An analysis on the factors affecting rice production efficiency in Myanmar. East. Asian Econ. Rev. 2015, 19, 167-188, . [CrossRef]

13. Linn, T.; Maenhout, B. Measuring the efficiency of rice production in Myanmar using data envelopment analysis. Asian J. Agric. Dev. 2019, 16, 1-24, . [CrossRef]

14. Padilla-Fernandez, M.D.; Nuthall, P.L. Technical efficiency in the production of sugar cane in central Negros area, Philippines: An application of data envelopment analysis. J. ISSAAS Int. Soc. Southeast Asian Agric. Sci. 2009, 15, 77-90.

15. Murali, P.; Prathap, D.P. Technical efficiency of sugarcane farms: An econometric analysis. Sugar Tech. 2017, 19, 109-116. [CrossRef]

16. Madau, F.A. Technical and scale efficiency in the Italian citrus farming. Empir. Econ. Lett. 2010, 9, 609-618.

17. Madau, F.A. Technical and scale efficiency in the Italian citrus farming: Comparison between SFA and DEA approaches. Agric. Econ. Rev. 2015, 16, 15-27. [CrossRef]

18. Skevas, T.; Lansink, A.O.; Stefanou, S.E. Measuring technical efficiency in the presence of pesticide spillovers and production uncertainty: The case of Dutch arable farms. Eur. J. Oper. Res. 2012, 223, 550-559. [CrossRef]

19. Skevas, T.; Lansink, A.O. Reducing pesticide use and pesticide impact by productivity growth: The case of Dutch arable farming. J. Agric. Econ. 2014, 65, 191-211. [CrossRef]

20. Lechenet, M.; Dessaint, F.; Py, G.; Makowski, D.; Munier-Jolain, N. Reducing pesticide use while preserving crop productivity and profitability on arable farms. Nat. Plants 2017, 3, 17008. [CrossRef]

21. Haruna, E.O.; Samuel, E.E.; Amechima, B. Data envelopment analysis approach to estimating economic and scale efficiency in processing cassava into Gari in Ankpa local area, Kogi State, Nigeria. Asian J. Agric. Ext. Econ. Sociol. 2020, 38, 16-24, . [CrossRef]

22. Laha, A.; Kuri, P.K. Measurement of allocative efficiency in agriculture and its determinants: Evidence from rural West Bengal, India. Int. J. Agric. Res. 2011, 6, 377-388, . [CrossRef]

23. Lohano, H.D.; Nazir, A.; Khushk, A.M. Technical, allocative and economic efficiencies in sugarcane production in Pakistan: A non-parametric approach. Bus. Rev. 2011, 6, 131-141.

24. Zulfiqar, F.; Shang, J.; Nasrullah, M.; Rizwanullah, M. Allocative efficiency analysis of wheat and cotton in district Khanewal, Punjab, Pakistan. GeoJournal 2020. [CrossRef]

25. Shaik, S.; Miljkovic, D. The impact of trade openness on technical efficiency in U.S. agriculture. J. Int. Agric. Trade Dev. 2011, 7, 131-144.

26. Hart, J.; Miljkovic, D.; Shaik, S. The impact of trade openness on technical efficiency in the agricultural sector of the European Union. Appl. Econ. 2015, 47, 1230-1247. [CrossRef]

27. Beltrán-Esteve, M. Assessing technical efficiency in traditional olive grove systems: A directional metadistance function approach. Econ. Agrar. Recur. Nat. 2013, 13, 53-76. [CrossRef]

28. Mulwa, R.; Emrouznejad, A. Measuring productive efficiency using Nervolian profit efficiency indicator and metafrontier analysis. Oper. Res. 2013, 13, 271-287. [CrossRef]

29. Khataza, R.R.B.; Hailu, A.; Doole, G.J.; Kragt, M.E.; Alene, A.D. Examining the relationship between farm size and productive efficiency: A Bayesian directional distance function approach. Agric. Econ. 2019, 50, 237-246. [CrossRef] 
30. Ray, S. The directional distance function and measurement of super-efficiency: An application to airlines data. J. Oper. Res. Soc. 2008, 59, 788-797. [CrossRef]

31. Atake, E.-H. Technical efficiency of public hospitals in Togo: A directional distance function approach. Econ. Bull. 2015, 35, 1752-1764.

32. Safiullah, M.; Shamsuddin, A. Technical efficiency of Islamic and conventional banks with undesirable output: Evidence from a stochastic meta-frontier directional distance function. Glob. Financ. J. 2020. [CrossRef]

33. Hug, A.A.; Arshad, F.M. Technical efficiency of chili production. Am. J. Appl. Sci. 2010, 7, 185-190.

34. Mohammed, B.; Ahmed, B.; Abdulsalam, Z. Technical efficiency of chili pepper production in Kaduna State, Nigeria. Am. J.Exp. Agric. 2015, 9, 1-9.

35. Asravor, J.; Onumah, E.E.; Osei-Asare, Y.B. Efficiency of chili pepper production in the Volta Region of Ghana. J. Agric. Ext. Rural. Dev. 2016, 8, 99-110. [CrossRef]

36. Hossain, M.M. Technical efficiency measurement of green chili production in Bogra District of Bangladesh. J. Stat. Appl. Probab. Lett. 2016, 3, 97-101. [CrossRef]

37. Pakpahan, H.T.; Nababan, M.B.P. The influences of chili input and technical efficiency of chili farmers in Lingga Village, North of Sumatera Province. Int. J. Progress. Sci. Technol. 2018, 7, 43-50.

38. Ngo, T.T.; Son, N.T.T.; Duong, T.N. Assessing the production efficiency of chili farmers in Tra Vinh Province. Sci. J. Tra Vinh Univ. 2019, 1, 1-10. [CrossRef]

39. Mariyono, J.; Sumarno, S. Chili production and adoption of chili-based agribusiness in Indonesia. J. Agribus. Dev. Emerg. Econ. 2015, 5, 57-75. [CrossRef]

40. Athipanyakul, T.; Pak-Uthai, W. Determinants of good agricultural practices (GAP) adoption in the chili production system in northeastern Thailand: A case of participatory approach. Int. J. Environ. Rural Dev. 2012, 3, 175-180.

41. Sriwaranun, Y.; Paku-Thai, W. The adoption of good agricultural practices for chili farming in Thailand. Acta Hortic. 2019, 1258, 183-188. [CrossRef]

42. Ooraikul, S.; Siriwong, W.; Siripattanakul, S.; Chotpantarat, S.; Robson, M. Risk assessment of organiphosphate pesticides for chili consumption from chili farm area, Ubon Ratchathani Province, Thailand. J. Health Res. 2011, 25, 141-146. Available online: https://he01.tci-thaijo.org/index.php/jhealthres/article/view/81160 (accessed on 12 January 2021).

43. Wanwimolruk, S.; Phopin, K.; Boonpangrak, S.; Prachayasittikul, V. Food safety in Thailand 4: Comparison of pesticide residues found in three commonly consumed vegetables purchased from local markets and supermarkets in Thailand. PeerJ 2016, 4, e2432. [CrossRef]

44. Van Asselt, E.D.; Banach, J.L.; van der Fels-Klerx, H.J. Prioritization of chemical hazards in spices and herbs for European Monitoring Programs. Food Control. 2018, 83, 7-17. [CrossRef]

45. Khaitov, B.; Yun, H.J.; Lee, Y.; Ruziev, F.; Le, T.H.; Umurzokov, M.; Bo Bo, A.; Cho, K.M.; Park, K.W. Impact of Organic Manure on Growth, Nutrient Content and Yield of Chili Pepper under Various Temperature Environments International. Int. J. Environ. Res. Public Health 2019, 16, 3031. [CrossRef] [PubMed]

46. Schreinemachers, P.; Schad, I.; Tipraqsa, P.; Williams, P.M.; Neef, A.; Riwthong, S.; Sangchan, W.; Grovermann, C. Can public GAP standards reduce agricultural pesticide use? The case of fruit and vegetable farming in northern Thailand. Agric. Hum. Values 2012, 29, 519-529. [CrossRef]

47. FAO. Development of a Framework for Good Agricultural Practices; Committee on Agriculture, Seventeenth Session Food and Agriculture Organization: Rome, Italy, 2003.

48. Ministry of Agriculture and Cooperatives. Good Agricultural Practices for Peppers. Royal Gaz.; Volume 122 Special Section 117D. Available online: https://www.acfs.go.th/standard/download/eng/GAP_peppers.pdf (accessed on 12 January 2021).

49. Siebrecht, N. Sustainable Agriculture and its implementation GAP_Overcoming obstacles to implementation. Sustainability 2020, 12, 3853. [CrossRef]

50. Hobbs, J.E. Incentives for the Adoption of Good Agricultural Practices (GAPs); Background Paper for the FAO Consultation on Good Agricultural Practices: Rome, Italy, 2003.

51. Oo, K.Y. Case Studies of Good Agricultural Practices (GAPS) of Farmers in Thailand; Center for Applied Economic Research, Kasetsart University: Bangkok, Thailand, 2016.

52. Hoang, H.G. Exploring farmers' adoption of VietGAP from systemic perspective: Implication for developing agri-food systems. Br. Food J. 2020, 122, 3641-3661. [CrossRef]

53. Calvin, L. Produce, food safety, and international trade: Response to U.S. foodborne illness outbreaks associated with imported produce. In International Trade and Food Safety: Economic Theory and Case Studies; Buzby, J., Ed.; USDA-Economic Research Service: Washington, DC, USA, 2003.

54. Subervie, J.; Vagneron, I. Can Fresh Produce Farmers Benefit from Global Gap Certification? The Case of Lychee Producers in Madagascar. In Proceedings of the Conference of International Association of Agricultural Economists, Foz do Iguacu, Brazil, 18-24 August 2012.

55. Huang, T.H.; Chiang, D.L.; Tsai, C.M. Applying the new metafrontier directional distance function to compare banking efficiencies in Central and Eastern European Countries. Econ. Model. 2015, 44, 188-199, . [CrossRef]

56. Färe, R.; Primont, D. Multi-Output Production and Duality: Theory and Applications; Kluwer Academic Publishers: Boston, MA, USA, 1995. 
57. Afriat, S.N. Efficiency estimation of production functions. Int. Econ. Rev. 1972, 13, 568-598. [CrossRef]

58. Watanabe, M.; Tanaka, K. Efficiency analysis of Chinese industry: A directional distance function approach. Energy Policy 2007, 35, 6323-6331, . [CrossRef]

59. Yahia, F.B.; Essid, H.; Rebai, S. Do dropout and environmental factors matter? A directional distance function assessment of Tunisian education efficiency. Int. J. Educ. Dev. 2018, 60, 120-127, . [CrossRef]

60. Goyal, J.; Singh, M.; Singh, R.; Aggarwal, A. Efficiency and technology gaps in Indian banking sector: Application of meta-frontier directional distance function DEA approach. J. Financ. Data Sci. 2019, 5, 156-172. [CrossRef]

61. Hayami, Y.; Ruttan, V.W. Agricultural Development: An. International Perspective; Johns Hopkins University Press: Baltimore, MD, USA, 1971.

62. Battese, G.E.; Rao, D.S.P. Technology gap, efficiency, and a stochastic metafrontier function. Int. J. Bus. Econ. 2002, 1, 87-93.

63. Battese, G.E.; Rao, D.S.P.; O'Donnell, C.J. A metafrontier production function for estimation of technical efficiencies and technology gaps for firms operating under different technologies. J. Prod. Anal. 2004, 21, 91-103. [CrossRef]

64. O'Donnell, C.J.; Rao, D.S.P.; Battese, G.E. Metafrontier frameworks for the study of firm-level efficiencies and technology ratios. Empir. Econ. 2008, 34, 231-255. [CrossRef]

65. Chambers, R.G.; Chung, Y.; Färe, R. Profits, directional distance functions, and Nerlovian efficiency. J. Optim. Theory Appl. 1998, 98, 351-364. [CrossRef]

66. Wang, K.; Xian, Y.; Lee, C.-Y.; Wei, Y.-M.; Huang, Z. On selecting directions for directional distance functions in a non-parametric framework: A review. Ann. Oper. Res. 2019, 278, 43-76. [CrossRef]

67. Färe, R.; Grosskopf, S. Theory and application of directional distance functions. J. Prod. Anal. 2000, 13, 93-103. [CrossRef]

68. Färe, R.; Grosskopf, S.; Margaritis, D. Advances in Data Envelopment Analysis; Now Publishers: Boston-Delft, MA, USA, 2015.

69. Athipanyakul, T. Economic, Social and Behavioral Factors Affecting Farmers' Decisions to Adopt GAP Technology for Chili Production in Chaiyaphoom Province; Report submitted to Thailand Research Grant Office: Bangkok, Thailand, 2012.

70. CEIC. Available online: https://www.ceicdata.com/en/thailand/producer-price-index-2010100-classification-of-productionby-activities-cpa/producer-price-index (accessed on 24 October 2020).

71. Krasachat, W. Technical inefficiency of chili farms in Thailand: A parametric approach. Test. Eng. Manag. 2020, 83, 30415-30421

72. Srisopaporn, S.; Jourdain, D.; Perret, S.R.; Shivakoti, G. Adoption and continued participation in a public good agricultural practices program: The case of rice farmers in the central plains of Thailand. Technol. Forecast. Soc. Chang. 2015, 96, 242-253. [CrossRef]

73. Laosutsan, P.; Shivakoti, G.P.; Soni, P. Factors influencing the adoption of good agricultural practices and export decision of Thailand's vegetable farmers. Int. J. Commons 2019, 13, 867-880, . [CrossRef] 